University of Nebraska - Lincoln

DigitalCommons@University of Nebraska - Lincoln

USDA National Wildlife Research Center - Staff Publications
U.S. Department of Agriculture: Animal and Plant Health Inspection Service

2011

\title{
Nilgai Antelope In Northern Mexico As A Possible Carrier For Cattle Fever Ticks And Babesia Bovis And Babesia Bigemina.
}

\author{
E M. Cardenas-Canales \\ Texas A\&M University-Kingsville, Caesar Kleberg Wildlife Research Institute
}

J. Alfonso Ortega-Santos

Tyler A. Campbell

USDA-APHIS-Wildlife Services, National Wildlife Research Center, tcampbell@eastfoundation.net

Zeferino Garcia-Vaquez

Centro Nacional de Investigación Disciplinaria en Parasitología Veterinaria (CENID PAVET), INIFAP,

Jiutepec, MorelosC.P. 62550, Mexico

Antonio Cantu-Covarrubias

Instituto Nacional de Investigaciones Forestales, Agrícolas y Pecuarias, Sitio Experimental

See next page for additional authors

Follow this and additional works at: https://digitalcommons.unl.edu/icwdm_usdanwrc

Part of the Environmental Sciences Commons, and the Life Sciences Commons

Cardenas-Canales, E M.; Ortega-Santos, J. Alfonso; Campbell, Tyler A.; Garcia-Vaquez, Zeferino; CantuCovarrubias, Antonio; Figueroa-Millian, Julio V.; DeYoung, Randy W.; Hewitt, David G.; and Bryant, Fred C., "Nilgai Antelope In Northern Mexico As A Possible Carrier For Cattle Fever Ticks And Babesia Bovis And Babesia Bigemina." (2011). USDA National Wildlife Research Center - Staff Publications. 1020.

https://digitalcommons.unl.edu/icwdm_usdanwrc/1020

This Article is brought to you for free and open access by the U.S. Department of Agriculture: Animal and Plant Health Inspection Service at DigitalCommons@University of Nebraska - Lincoln. It has been accepted for inclusion in USDA National Wildlife Research Center - Staff Publications by an authorized administrator of DigitalCommons@University of Nebraska - Lincoln. 


\section{Authors}

E M. Cardenas-Canales, J. Alfonso Ortega-Santos, Tyler A. Campbell, Zeferino Garcia-Vaquez, Antonio Cantu-Covarrubias, Julio V. Figueroa-Millian, Randy W. DeYoung, David G. Hewitt, and Fred C. Bryant 


\title{
Nilgai Antelope in Northern Mexico as a Possible Carrier for Cattle Fever Ticks and Babesia bovis and Babesia bigemina
}

\begin{abstract}
Elsa M. Cárdenas-Canales, ${ }^{1}$ J. Alfonso Ortega-Santos, ${ }^{1,5}$ Tyler A. Campbell, ${ }^{2}$ Zeferino García-Vázquez, ${ }^{3}$ Antonio Cantú-Covarrubias, ${ }^{4}$ Julio V. Figueroa-Millán, ${ }^{3}$ Randall W. DeYoung, ${ }^{1}$ David G. Hewitt, ${ }^{1}$ and Fred C. Bryant ${ }^{1}{ }^{1}$ Caesar Kleberg Wildlife Research Institute, Texas A\&M University-Kingsville, Kingsville, Texas 78363, USA; ${ }^{2}$ US Department of Agriculture, Animal and Plant Health Inspection Service, Wildlife Services, National Wildlife Research Center, Texas Field Station, Kingsville, Texas 78363, USA; ${ }^{3}$ Centro Nacional de Investigación Disciplinaria en Parasitología Veterinaria (CENID PAVET), INIFAP, Jiutepec, Morelos C.P. 62550 , México; ${ }^{4}$ Instituto Nacional de Investigaciones Forestales, Agrícolas y Pecuarias, Sitio Experimental Aldama, Aldama, Tamaulipas C.P. 89670, México; ${ }^{5}$ Corresponding author (email: poncho.ortega@ tamuk.edu)
\end{abstract}

ABSTRACT: Of 20 blood samples from nilgais from México, five were polymerase chain reaction-positive for Babesia bigemina and one for Babesia bovis. Positive samples had the expected 170 (B. bigemina) and 291 (B. bovis) base pairs and were identical to GenBank B. bigemina accession S45366 and B. bovis M38218.

Understanding the impact of wildlife diseases on wildlife populations has become a recent issue of global priority. Knowledge of such impacts is critical when disease risks involve not only wild populations but also human health and livestock industries. Such is the case with bovine babesiosis in the border region of México and the USA. Bovine babesiosis is a common and widely distributed arthropod-transmitted disease (Homer et al., 2000) and is considered the most economically important disease of livestock (Bock et al., 2004). The disease is caused by the protozoan parasites Babesia bigemina and Babesia bovis, transmitted to the host by the tick vectors Rhipicephalus annulatus and Rhipicephalus microplus (Bock et al., 2004), known as cattle fever ticks (CFTs). Although cattle are the main host for CFTs, other ungulates such as white-tailed deer (Odocoileus virginianus; Hagan and Bruner, 1951; Cantú et al., 2007), sheep (Ovis aries; Mungall and Sheffield, 1994), and nilgai antelope (Boselaphus tragocamelus; Sheffield et al., 1983) have been found with CFTs.

Nilgai antelope are an exotic species introduced into Texas, USA, in the 1940s (Sheffield et al., 1983). They successfully adapted to this range, and their numbers have been increasing. Approximately
30,000 nilgai are found along the TexasMéxico border in the quarantine zone (APHIS, 2006). Because nilgai can interchange freely across the border, the likelihood of nilgai acquiring bovine babesiosis is high.

The role that nilgai antelope may play in bovine babesiosis is unknown. No study has investigated whether nilgai are susceptible to Babesia spp. Because other wildlife species are known to become infected with Babesia spp., determining whether nilgai antelope may serve as a carrier for the parasite is critical, particularly in areas where cattle and nilgai coexist. Our objective was to look for evidence of B. bovis and B. bigemina and CFTs in nilgai antelope in México.

The study was conducted on a private ranch in the state of Coahuila, México (approximately $67^{\circ} 33^{\prime} \mathrm{N}, 43^{\circ} 78^{\prime} \mathrm{E}$ ). Our study area was a 2,765-ha high-fenced area within the 4,218-ha ranch. In addition to nilgai, other free-ranging native and exotic species were present, including white-tailed deer, black buck (Antilope cervicapra), blue wildebeests (Connochaetes taurinus), zebras (Equus zebra), and giraffe (Giraffa camelopardalis). Cattle had been removed from the area for approximately $10 \mathrm{yr}$. Nilgai of all ages and both sexes were harvested $(n=20$ during the day by waiting for animals at watering points and at night by spot-lighting along roads. Research was performed under a scientific collecting permit issued by the Subsecretaria de Recursos Naturales, Dirección de Recursos Forestales y Vida Silvestre del Estado de Coahuila. Two 
TABle 1. Nucleotide sequence of primers used for PCR and nested PCR to detect Babesia spp. in México (Figueroa et al., 1993).

\begin{tabular}{|c|c|c|}
\hline Organism & Primer sequence ${ }^{\mathrm{a}}$ & Product length (base pairs) \\
\hline \multicolumn{3}{|c|}{ Babesia bigemina } \\
\hline Simple PCR & $\begin{array}{l}\mathrm{F}: 5^{\prime} \text {-CCTCGGCTTCAACTCTGATGCCAAAG-3' } \\
\mathrm{R}: 5^{\prime} \text {-CATCTAATTTCTCTCCATACCCCTCC-3' }\end{array}$ & 278 \\
\hline Nested PCR & $\begin{array}{l}\text { F: 5'-CGCAAGCCCAGCACGCCCCGGTGC-3' } \\
\text { R: 5'-CCGACCTGGATAGGCTGTGATG-3' }\end{array}$ & 170 \\
\hline \multicolumn{3}{|l|}{ Babesia bovis } \\
\hline Simple PCR & $\begin{array}{l}\mathrm{F}: \text { 5'-CACGAGGAAGGAACTACCGATGTTGA-3' } \\
\mathrm{R}: 5^{\prime} \text {-CCAAGGAGCTTCAACGTACGAGGTCA-3' }\end{array}$ & 350 \\
\hline Nested PCR & $\begin{array}{l}\text { F: 5'-TCAACAAGGTACTCTATATGGCTACC-3' } \\
\text { R: 5'-CTACCGAGCAGAACCTTCTTCACCAT-3' }\end{array}$ & 291 \\
\hline
\end{tabular}

${ }^{\mathrm{a}} \mathrm{F}=$ forward; $\mathrm{R}=$ reverse.

blood samples, one sample for whole blood and second sample for serum, were collected from the jugular vein or the heart of each animal, generally within 15 min after harvest. Animals were thoroughly inspected (Pelzel, 2005) in searching for ticks. Blood was stored at $4 \mathrm{C}$ until further transportation to the National Center of Disciplinary Research in Animal Parasitology (CENID-PAVET), Jiutepec, Morelos, México.

Simple PCR was performed on blood samples, followed by a nested PCR (nPCR) from the product to increase the detection of the expected fragments. Before DNA extraction, blood samples were pretreated with saponin to facilitate lysis (Figueroa et al., 1992). The protocols for PCR and nPCR amplification and primer sequences identifying the gene Rap-1 for B. bovis and B. bigemina (Table 1) followed Figueroa et al. (1993). The protocol followed for the nPCR was identical to the simple PCR. We used positive controls derived from an in vitro culture for both Babesia spp. and DNA from a cow free of Babesia spp. as a negative control. For the simple PCR protocol, amplicon expected sizes were 278 and 350 base pairs (bp) for $B$. bigemina and B. bovis, respectively. The resulting amplicons from positive samples had the expected sizes of $170 \mathrm{bp}$ ( $B$. bigemina) and $291 \mathrm{bp}$ (B. bovis) and were identical to published sequences of both species (B. bigemina GenBank accession S45366; B. bovis accession M38218). Amplified products were visualized using gel electrophoresis on a $2 \%$ agaroseethidium bromide gel (Promega, Madison, Wisconsin, USA) by using a 123-bp ruler (Invitrogen, Carlsbad, California, USA).

We documented five samples positive for B. bigemina based on amplicon size (170 bp), of which one sample also was positive for B. bovis (291 bp). The most important finding of this research is the presence of B. bovis and B. bigemina in free-ranging nilgai. No ticks were found on any of the harvested animals. Our PCR findings demonstrate the apparent presence of babesial parasite DNA in nilgai blood cells; however, these results do not address whether B. bigemina and B. bovis can complete their life cycles in nilgai. It also is unknown whether nilgai are susceptible to Babesia spp. infection, develop the clinical phase, and remain infective, thereby making them reservoirs. Further studies are needed to conclude that nilgai antelope act as a competent reservoir of Babesia spp.

Even though cattle were removed from the ranch, we did not disregard the possibility that CFTs were present on the study area maintained solely by wildlife. Kistner and Hayes (1970) reported whitetailed deer infested with CFTs in an area 
where cattle were absent for $>20 \mathrm{yr}$. The reason that no ticks were found on any Babesia-positive animals is unknown.

Evidence of Babesia spp. in nilgai has not been reported previously. The role of nilgai in bovine babesiosis cannot be determined from this study; however, nilgai cannot be disregarded as a potential reservoir of bovine babesiosis. Important modifications to CFT eradication strategies may need to be implemented if nilgai antelope are capable of disseminating CFTs and therefore maintaining bovine babesiosis.

We acknowledge USDA-APHIS, the Caesar Kleberg Wildlife Research Institute, and David Killam for provided funding; the Asociación Nacional de Ganaderos Diversificados y Criadores de Fauna for support during the fieldwork; and the CENID-PAVET from INIFAP for contributions to the laboratory analyses. This is a Caesar KleberWildlife Research publication 10-102.

\section{LITERATURE CITED}

[APHis] Animal and Plant Health Inspection. 2006. News Release. USDA celebrates 100-year anniversary of fever tick eradication program, http://www.aphis.usda.gov/newsroom/content/2006/ 07/txticks.shtml. Accessed September 2007.

Bock, R., L. Jackson, A. De Vos, and W. Jorgensen. 2004. Babesiosis of cattle. Parasitology 129: S247-S269.

Cantú, A., J. A. Ortega, J. Mosqueda, Z. GarcíaVázquez, S. E. Henke, and J. E. George. 2007.
Immunologic and molecular identification of Babesia bovis and Babesia bigemina in freeranging white-tailed deer in Northern México. Journal of Wildlife Diseases 43: 504-507.

Figueroa, J. V., L. P. Chieves, G. S. Johnson, and G. M. Buening. 1992. Detection of Babesia bigemina-infected carriers by polymerase chain reaction amplification. Journal of Clinical Microbiology 30: 2576-2582. plex polymerase chain reaction based assay for the detection of Babesia bigemina, Babesia bovis and Anaplasma marginale DNA in bovine blood. Veterinary Parasitology 50: 69-81.

Hagan, W. A., and D. W. Bruner. 1951. The infectious diseases of domestic animals, 2nd Edition. Comstock Publishing Associates, Ithaca, New York. 920 pp.

Homer, M. J., I. Aguilar-Delfin, S. R. Telford, III, P. J. Krause, and D. H. Persing. 2000. Babesiosis. Clinical Microbiology Reviews 13: 451-469.

Kistner, T. P., and F. A. Hayes. 1970. White-tailed deer as hosts of cattle fever-ticks. Journal of Wildlife Diseases 6: 437-440.

Mungall, E. C., And W. J. Sheffield. 1994. Exotics on the range: The Texas example. Texas A\&M University Press, College Station, Texas. pp. 265.

Pelzel, A. M. 2005. Cattle fever tick surveillance in Texas. National Animal Health Surveillance System Outlook, www.aphis.usda.gov/vs/ceah/ ncahs/nsu/outlook. Accessed June 2009.

Sheffield, W. J., B. A. Fall, and B. A. Brown. 1983. The nilgai antelope in Texas. Report. RM13/ KS5. The Texas Agricultural Experiment Station, College Station, Texas. 100 pp.

Submitted for publication 16 August 2010. Accepted 5 February 2011. 